\title{
Potential of Certain Salts and Fungicides to Control Postharvest Gray Mould (B. cinerea) of Strawberry
}

\author{
Gehad M.M. Abd El-Wahab' ${ }^{1}$, Fayza A. Seddik² and Manal A.A. Abdel razik ${ }^{3}$ \\ ${ }^{1}$ Vegetable Diseases Research Dept., Plant Pathology Res. Inst., ARC, Giza, Egypt. \\ ${ }^{2}$ Pesticide Residues and Environmental Pollution Dept., Central Laboratory, El Dokki, Egypt. \\ ${ }^{3}$ Pesticides department and Faculty of Agriculture, Menoufia University, Egypt
}

\begin{abstract}
Effect of two fungicides (i.e. iprodione and cyprodinil+flydioxonil mixture) and two salts (sodium bicarbonate, SBC, and sodium benzoate, SBO) were evaluated separately or in mixtures in laboratory experiments as well as under field conditions against Botrytis cinerea instant of the fruit gray mould of strawberry. All tested salts and fungicides as well as their mixtures significantly decreased the radial growth of $B$. cinerea in vitro. Complete inhibition of radial growth was obtained with SBC at 2.0 and $1.0 \mathrm{~g} / 100 \mathrm{ml}$. Also, high reductions were obtained with SBC at lower concentrations. The fungicide iprodione at $500 \mathrm{mg} / \mathrm{L}$ completely inhibited radial growth of $B$. cinerea, while complete inhibition was obtained with cyprodinil+flydioxonil at lower concentration $(10 \mathrm{mg} / \mathrm{L})$. Mixing the tested fungicides with salts increased their inhibition effect on $B$. cinerea growth at lower fungicide concentrations. iprodione at $0.1 \mathrm{mg} / \mathrm{L}$ mixed with $\mathrm{SBO}$ at $1 \mathrm{~g} / 100 \mathrm{ml}$ completely inhibited radial growth. Also, cyprodinil+flydioxonil at $0.1 \mathrm{mg} / \mathrm{L}$ mixed with $\mathrm{SBC}$ at $0.2 \mathrm{~g} / 100 \mathrm{ml}$ completely inhibited radial growth of $B$. cinerea while $0.001 \mathrm{mg} / \mathrm{L}$ cyprodinil+flydioxonil fungicide with $\mathrm{SBO}$ at $2.0 \mathrm{~g} / 100$ completely inhibited radial growth. On the other hand, the field experiments showed that all treatments with the tested salts and fungicides significantly decreased postharvest Botrytis gray mould on fruits harvested 1, 3, 7, 10 and 15 days after treatments and stored at $5^{\circ} \mathrm{C}$ for seven days. However, the treatment with $50 \%$ cyprodinil+flydioxonil $+\mathrm{SBC} 2 \%$ was the most effective and decreased mean percentage of infection to $4 \%$ compared to $23.86 \%$ for the untreated control. This was followed by $50 \%$ iprodione + SBC $2 \%, 25 \%$ iprodione + SBC and $25 \%$ cyprodinil+flydioxonil + SBC $2 \%$, and cyprodinil+flydioxonil, alone, and iprodione, alone, with percentages of infection being $7 \%, 8 \%, 8.5 \%, 8.5 \%$, and $9 \%$, respectively, while (SBC 2\%, alone) treatment showed the least effect with 12.93 percentage of infection. Meanwhile, positive strong correlations ( $\mathrm{r}=0.981$ to 0.943 ) were revealed between Infection (\%) and harvest interval periods with two salts mixed with iprodione and cyprodinil + flydioxonil after stored at $5^{\circ} \mathrm{C}$. Also, the enzyme assay revealed that increases in the activity levels of pectolytic and cellulytic enzymes produced by the fungus were associated with high fruit rots incited by $B$. cinerea. Meanwhile, residues of all tested fungicides in treated strawberry fruits decreased with decreasing fungicide concentrations in the salt + fungicide mixtures. cyprodinil $(25 \%)+$ SBO, and cyprodinil $(25 \%)+$ SBC treatments exhibited the lowest residue values being 1.420 , and $1.680 \mathrm{mg} / \mathrm{kg}$ fruit one hour after treatment while the other treatments showed higher residue values while the highest was recorded for iprodion at recommend dose being 29.81 $\mathrm{mg} / \mathrm{kg}$ fruit. However, fungicide residues decreased with increasing time after preharvest treatments.
\end{abstract}

Key words: strawberry, gray mould, fungicides, sodium bicarbonate, sodium benzoate, $B$. cinerea .

\section{INTRODUCTION}

Strawberry (Fragaria X ananassa Duchesne) is an important and high-value crop worldwide. It is an excellent source of vitamin $\mathrm{C}$, which contains an average 40-90 mg. Egypt is considered the third largest producer of strawberry in the world after the United States and Spain (Wu et al, 2012). In Egypt, strawberry is one of the most important vegetable crops for local consumption and exportation (Embaby et al., 2016, and Barakat and Al-Masri, 2017). Unfortunately, strawberry is affected by several plant diseases that affect its yield and quality in both the pre- and post-harvest stages. Gray mold of strawberry caused by $B$. cinerea is one of the most important post-harvest diseases worldwide (Williamson et al., 2007). However, B. cinerea can attack strawberry during all growth stages (flowering, fruiting and storage periods) causing destructive rots. $B$. cinerea is considered the main causal pathogen of strawberry postharvest decay (Sesan, 2003 and Droby and Lichter, 2004).
Traditionally, chemical fungicides have been used to maintain high quality of fruits and vegetables over extended periods of storage or transportation. However, the increased global chemo phobia and the reduced efficacy of chemicals due to pathogen resistant strains, have forced producers and researchers to search for more safe alternatives for controlling such postharvest diseases and to minimize the use of chemical fungicides to ensure good fruit quality (Sanzani, et al., 2009).

In this context, there is a considerable interest in the use of bicarbonates for controlling various fungal diseases in plants (Smilanick et al., 1999 and Pankaj and singh, 2017), as these salts are inexpensive, easy, safe in application, and nonhazardous for humans and the environment. Sodium salts were shown to inhibit fungal pathogens of fruits, field crops, vegetables and ornamentals (Oliver et al., 1999 and Melanie et al., 2002). Sodium benzoate is a preservative which is bacteriostatic and fungistatic under acidic 
conditions. Also, sodium bicarbonate (NaHCO3), commonly known as baking soda, shown antimicrobial activity and has been used to control rots caused by Phytophthora infestans (Mills et al., 2004), Penicillium digitatum (Smilanick et al., 1999), Penicillium expansum (Wan et al., 2003) and $B$. cinerea in table grape, tomato, apple, and cherry (Droby et al., 2003, Ippolito et al., 2005, Nigro et al., 2006, and Fayza et al., 2017).

Consequently, the objectives of the present study was to evaluate the potential of the antimicrobial effect of sodium biocarbonate and sodium benzoate salts singly or in mixtures with low doses of fungicides (i.e. iprodione and cyprodinil+fludioxonil mixture) for the inhibition of mycelial growth of B.cinerea in vitro and under field conditions to control postharvest gray mould of strawberry during storage. In addition, effects of such treatments were evaluated for pectinase (PC) and celluloses (CX) produced in fruits by fungal pathogen, as well as the influence of these treatments on the residue levels of these fungicides in treated strawberry fruits.

\section{MATERIALS AND METHODS}

\section{1- Fungal culture.}

Fruit samples of strawberry showing gray mould symptoms were collected during 2015-2016 winter season from different fields (fresh planting) in El Tahreir region. Diseased fruits were rinsed several times in sterilized water; surface disinfested using $70 \%$ ethyl alcohol for two minutes and dried between sterilized filter papers, cut into small pieces, each containing diseased tissues with adjacent healthy ones. Sample pieces were, then, cultured on PDA medium and incubated for 4 days at $24{ }^{\circ} \mathrm{C}$. The growing fungi were purified by using single spore isolation technique and were identified according to Gilman (1957) and Barnett and Hunter (1972) and transferred on PDA slants.

\section{1- The in vitro effect of certain salts, fungicides} on mycelial growth of $B$. cinerea.

Sodium bicarbonate and sodium benzoate (Sigma) were mixed with sterilized and nonsolidified PDA media at the concentrations 2.0, 1.0, $0.5,0.2,0.05$ and $0.02 \%$, while the fungicides at concentrations of $500,100,10,1,0.1,0.01$ and 0.001 a.i. $\mathrm{mg} / \mathrm{L}$ for iprodione and mixture of cyprodinil+flydioxonil Table (1) were prepared in distilled water and incorporated into the molten PDA before pouring the plates, $20 \mathrm{ml}$ of PDA/plate (Smilanick et al., 2008). Petri plates were then, inoculated in the center with $0.7 \mathrm{~cm}$ diameter mycelium disks of 5-day- old culture of $B$. cinerea and incubated at $20^{\circ} \mathrm{C}$. Diameters of the developed colonies were measured in $\mathrm{cm}$ daily until the fungal colonies in controls reached the edge of the plates (Sabebaro et al., 2014, and EL-Mougy et al., 2015).

\section{2- The in vitro effect of salt and fungicide} mixtures to inhibit the growth of $B$. cinerea.

Sodium bicarbonate at the concentrations of $0.20,0.10$ and $0.05 \%$ and sodium benzoate at the concentrations of $2.0,1.0$ and $0.5 \%$, while the fungicides at concentrations of $10,1.0$ and 0.1 a.i $\mathrm{mg} / \mathrm{L}$ for iprodione and 0.1, 0.01 and .001 a.i. $\mathrm{mg} / \mathrm{L}$ for the cyprodinil+flydioxonil mixture (Smilanick $e t$ al., 2008), were tested in combination for their inhibitory effect on the mycelial growth of $B$. cinerea.

\section{Filed experiments:}

Field experiments were conducted at El-Tahreer regions during 2016-2017 winter season. Healthy strawberry transplants cv. Festival were used. Salts and fungicides, (iprodion, Rovral, 50\%WP, and cyprodinil+flydioxonil mixture, Switch, $62.5 \% \mathrm{WG}$ ) were prepared in water and sprayed (at recommended dosage, half and fourth recommended dosage mixing with salts at $2 \%$ ) two times a week before harvest (preharvest) in 15thJanuary at the beginning of the flowering stage, when $10-20 \%$ of the flowers had opened and at $50-75 \%$ bloom (Blacharski et al., 2001 and Haydu, 2003), four replicates were prepared for each treatment each contained 50 plants. Check treatment was sprayed with water. Plants were managed as usual for strawberry cultivation but no fungicides were applied except the tested treatments.

Fruits from the different treatments, as well as controls were collected 1, 3, 7, 10 and 15 days after the second spray application at random from sampling, and placed in sterilized plastic container contained ice packages. Fruits were incubated at $5^{\circ} \mathrm{C}$ for 7 days and observed daily for Botrytis fruit rot development (Hongyin et al., 2007).

Table 1: Chemical name, common name, recommended dose and active ingredient of the investigated fungicide were as follows:

\begin{tabular}{|c|c|c|c|c|}
\hline Fungicide & Chemical name & $\begin{array}{l}\text { Trade } \\
\text { name }\end{array}$ & $\begin{array}{l}\text { Dose/ } \\
100 \mathrm{~L}\end{array}$ & $\begin{array}{c}\text { Active ingredient } \\
\text { (ai) }\end{array}$ \\
\hline Switch $62.5 \%$ & $\begin{array}{l}\text { 4-cyclopropyl-6-methyl-N-phenyl-2- } \\
\text { pyrimidinamine }+4 \text {-(2,2-difluoro-1,3- } \\
\text { benzodioxol-4-yl)-1H-pyrrole-3-carbonitrile }\end{array}$ & Switch & $75 \mathrm{~g}$ & $\begin{array}{l}\text { cyprodynil+ } \\
\text { flydioxyonil }\end{array}$ \\
\hline Rovral 50\% & $\begin{array}{l}\text { 3-(3,5-dichlorophenyl)-N-(1-methylethyl)- } \\
\text { 2,4-dioxo-1-imidazolidinecarboxamide }\end{array}$ & Rovral & $90 \mathrm{~g}$ & iprodione \\
\hline
\end{tabular}


Percentage of infection with Botrytis gray mold on strawberry fruits was calculated at the end of storage as follow:

$$
\text { Infection }(\%)=\text { Number of rotted fruits } \times 100
$$

Total number of tested fruits

\section{1- Assessment of cellulose and pectinase activities:}

Activities of pectinase (PC) and cellulase (CX) enzymes produced by $\mathrm{B}$. cinerea in stored strawberry fruits were determined under laboratory conditions according to methods described by Talboys and Busch (1970) in fruit tissue extract prepared by Luke et al. (1981) The reduction in viscosity of the reaction mixtures containing $2 \mathrm{ml}$ of crude enzyme (tissue extract), $5 \mathrm{ml}, 1.5 \%$ citrus pectin solution in $0.1 \mathrm{M}$ phosphate buffer at $\mathrm{PH} 5$ adjusted by $0.3 \mathrm{M} \mathrm{Na} \mathrm{OH}$ or $\mathrm{HCl}$. The reaction mixtures were incubated at $28^{\circ} \mathrm{C}$ and the loss in viscosity of the mixture was measured after 30 minutes against blank containing boiled inactivated extracts. PC and CX activity assay methods were based on the loss in viscosity by the Fenske-Ostwald viscometer, according to (Bell et al., 1955).

Loss in viscosity $(\%)=\frac{\mathrm{T} 0-\mathrm{T} 1 \times}{\mathrm{T} 0-\mathrm{TW}} 100$

$\mathrm{T} 0=$ time of flow blank (zero time)

$\mathrm{T} 1=$ the time of flow at a given time interval

$\mathrm{Tw}=$ the time of flow to distilled water

\section{2- Determination of fungicide residues:}

Strawberry fruits were obtained from the field experiment at the different intervals $(0,3,7,10,15$ days) after last spray. Three replicates, $350 \mathrm{~g}$ from each treatment as well as the control, were put in polyethylene bags. The three replicates were mixed to form one representative sample and homogenized. Two sub-samples each $50 \mathrm{~g}$ were taken, one for extraction instantly and the second was kept in a deep freezer at $-20{ }^{\circ} \mathrm{C}$ as a stock.

Multi residue method: AOAC (1995) was followed with some modification where the sample and solvent volume were only half of those in the AOAC method and a rotary evaporator and blowing down with air. After drying, pesticide residues were reconstituted in n-hexane/acetone for gas chromatography determination according to (Abada et al., 2005).

\section{Statistical analysis:}

All data were statistically analyzed and means were compared using LSD test at 5\% level of probability according at Gomez and Gomez (1984). All statistical analyses were performed using analysis of variance technique by means on Costat (1985) computer software package.

\section{RESULTS AND DISCUSSION}

\section{Laboratory Experiments}

1.1. The in vitro effect of certain salts and fungicides on growth of $B$. cinerea.

Results illustrated in Figure 1 (A and B) showed that both of the tested salts (SBC \& SBO) significantly decreased the radial growth of $B$. cinerea. However, complete inhibition of radial growth was obtained with SBC at 2.0 and $1.0 \mathrm{~g} / 100$ $\mathrm{ml}$. Also, high reductions were obtained with SBC at lower concentrations of $0.50,0.20$ and $0.10 \mathrm{~g} /$ $100 \mathrm{ml}$, where mean radial diameter decreased to $1.50,2.77$ and $3.55 \mathrm{~cm}$, respectively, compared to $9.0 \mathrm{~cm}$ for the untreated control. Meanwhile, the illustrated data showed that use of SBO at 2.0, 1.0 and $0.5 \mathrm{~g} / 100 \mathrm{ml}$ decreased mean radial diameter to $1.65,3.00$ and $4.58 \mathrm{~cm}$, respectively.

On the other hand, data illustrated in Figures 1 ( $\mathrm{C}$ and $\mathrm{D})$ showed that the two tested fungicides i.e., iprodione and mixture cyprodinil+flydioxonil significantly decreased radial growth of $B$. cinerea at the different tested concentrations. iprodione fungicide at $500 \mathrm{mg} / \mathrm{L}$ completely inhibited radial growth of $B$. cinerea, while concentrations of 100 and $10 \mathrm{mg} / \mathrm{L}$ decreased radial growth (diameter) to 1.58 and $2.07 \mathrm{~cm}$, respectively, compared to $9.0 \mathrm{~cm}$ for the untreated control.

However, complete inhibition was obtained with cyprodinil+flydioxonil low concentrations of 100 and $10 \mathrm{mg} / \mathrm{L}$. Also, high reductions of radial growth were obtained being $1.85,2.67,4.00$ and $4.67 \mathrm{~cm}$ at lower concentrations of $1.0,0.10,0.01$ and 0.001 $\mathrm{mg} / \mathrm{L}$, respectively. These findings are in harmony with those of Palmer et al. (1997) and Nigro et al. (2006) who reported that sodium bicarbonates inhibited radial growth of $B$. cinerea. Also, Zaker (2014) showed that potassium and sodium bicarbonate were effective in reducing growth and spore germination of B. cinerea. Also, Helalia and Sameer (2014) indicated similar results with SBC which caused inhibition rates ranged between 7.44 and $87.00 \%$ on radial growth of $P$. digitatum when SBC applied at 250- $3000 \mu \mathrm{g} / \mathrm{ml}$. Meanwhile, ElGamal et al. (2014) found that sodium benzoate, at concs., $0.25,0.5,1.0$ and $1.5 \%$, significantly decreased the radial growth of Alternaria alternata and Rhizopus stolonifer. Also, they indicated that $1.0 \%$ for sodium benzoate showed high radial growth reduction by $63.3 \%$ and $61.1 \%$, respectively, compared to the untreated control. Such results are in harmony with those reported by (Menzel et al., 2016 and Barakat and Al-Masri, 2017). 


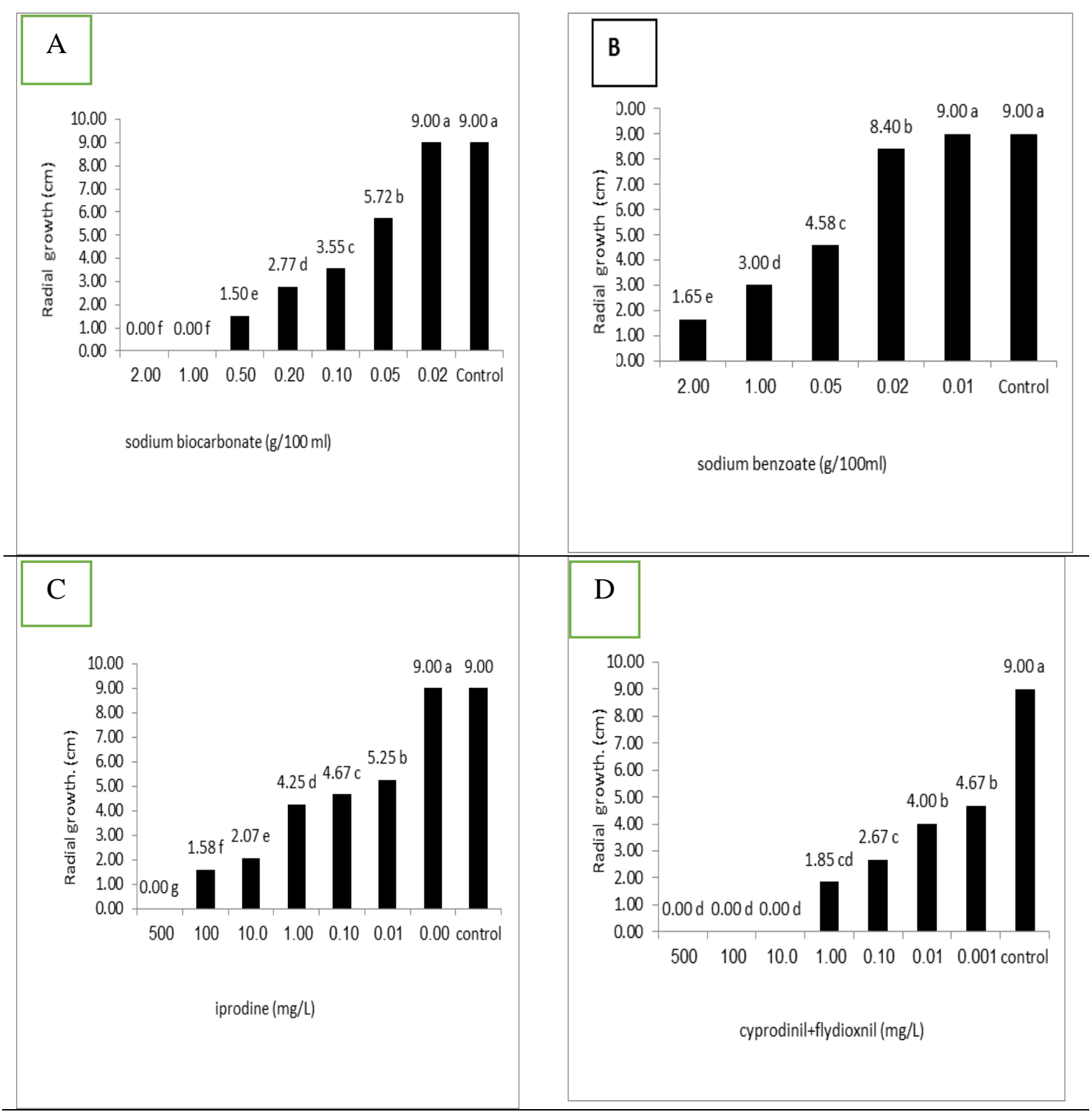

Figure 1: The in vitro effect of different concentrations of sodium bicarbonate (A) \& sodium benzoate (B) salts and iprodione (C) and cyprodinil+flydioxonil (D) fungicides on radial growth of $B$. cinerea.

1.2. The in vitro effect of salt and fungicide mixtures to inhibit the growth of $B$. cinerea.

It is evident from Figure (2) that SBC supplemented with each of the two tested fungicides were effectively in suppress the in vitro $B$. cinerea radial growth, compared to the untreated control. Meanwhile, data presented in Table (2) illustrated in Figure (3) showed that mixing the tested salts with fungicides increased their inhibition effect on B. cinerea growth at the lower fungicide concentrations. SBC at $0.2 \mathrm{mg} / 100 \mathrm{ml}$ mixed with iprodione at a.i. $1.00 \mathrm{mg} / \mathrm{L}$ was the most effective and decreased radial growth diameter of $B$. cinerea to $1.933 \mathrm{~cm}$, compared to $9.0 \mathrm{~cm}$ for the untreated control, while all tested SBC and iprodione combinations (i.e. SBC, 0.2, 0.1, $0.05 \mathrm{x}$ iprodion, $1.0,0.1,0.01)$ resulted in radial growth ranged between $1.933 \mathrm{~cm}$ and $5.767 \mathrm{~cm}$, compared to 9.0 $\mathrm{cm}$ for the untreated control.

However, SBC at $0.2 \mathrm{~g} / 100 \mathrm{ml}$ mixed with cyprodinil+flydioxonil at $0.1 \mathrm{mg} / \mathrm{L}$ completely inhibited radial growth of B. cinerea, while other combinations resulted in radial growth ranged between $0.800 \mathrm{~cm}$ and $2.833 \mathrm{~cm}$, compared to 9.0 $\mathrm{cm}$ for the untreated control. 


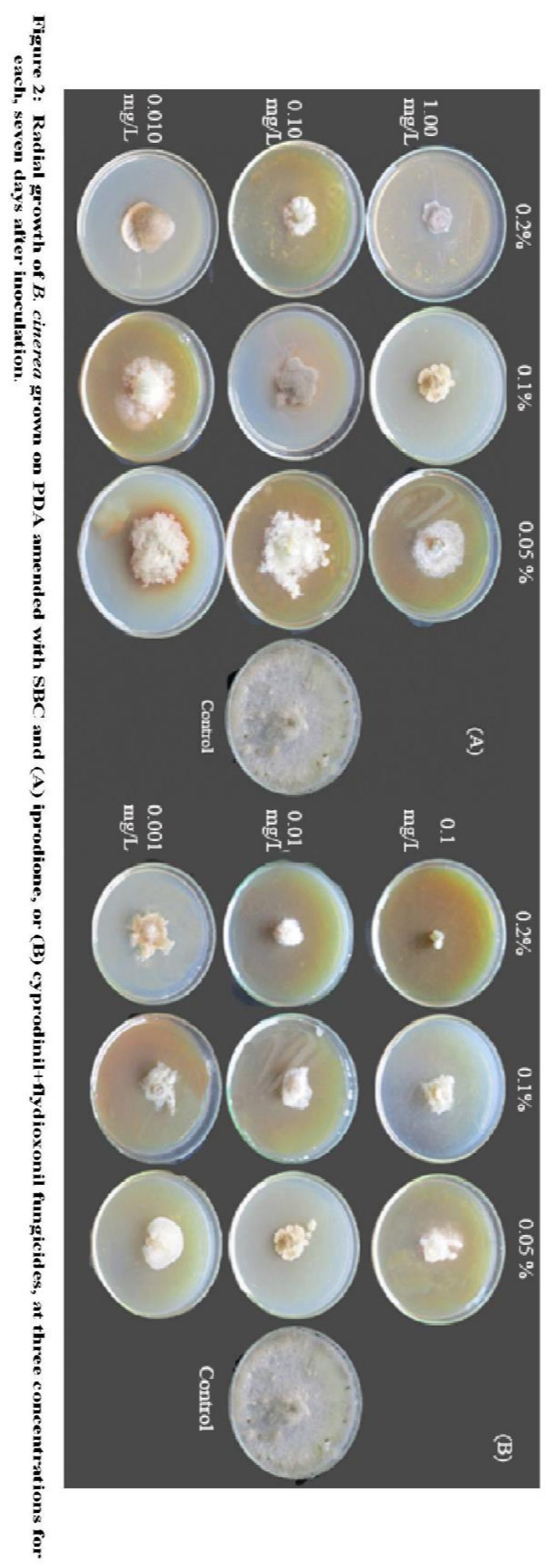




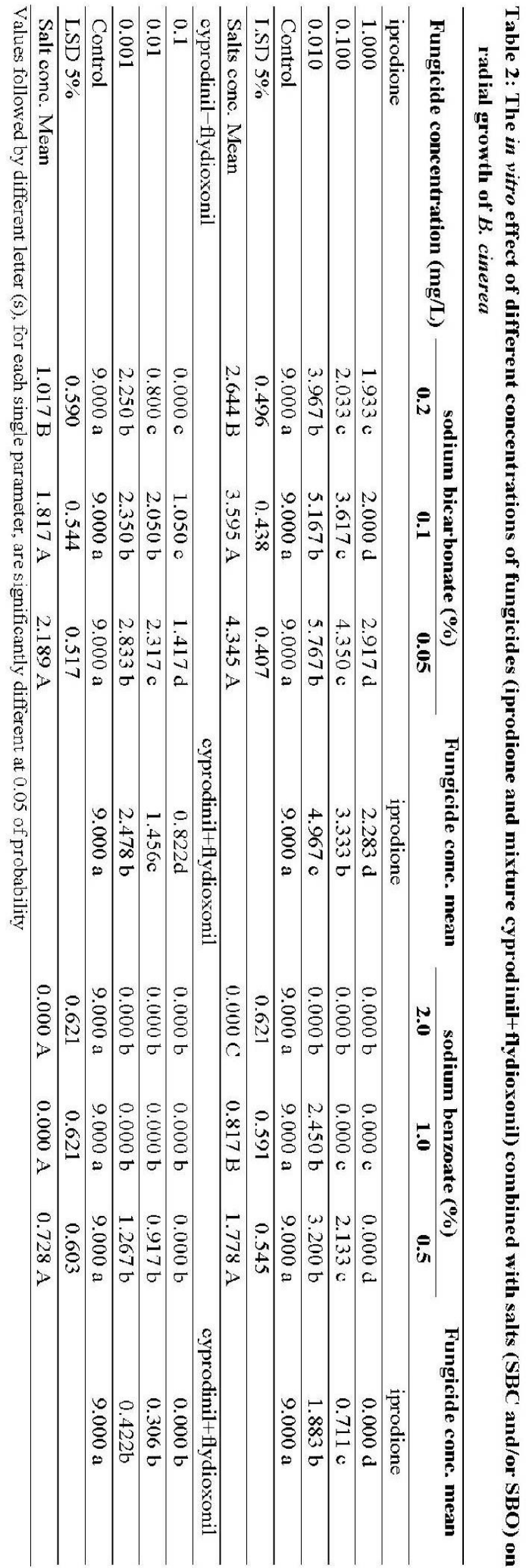




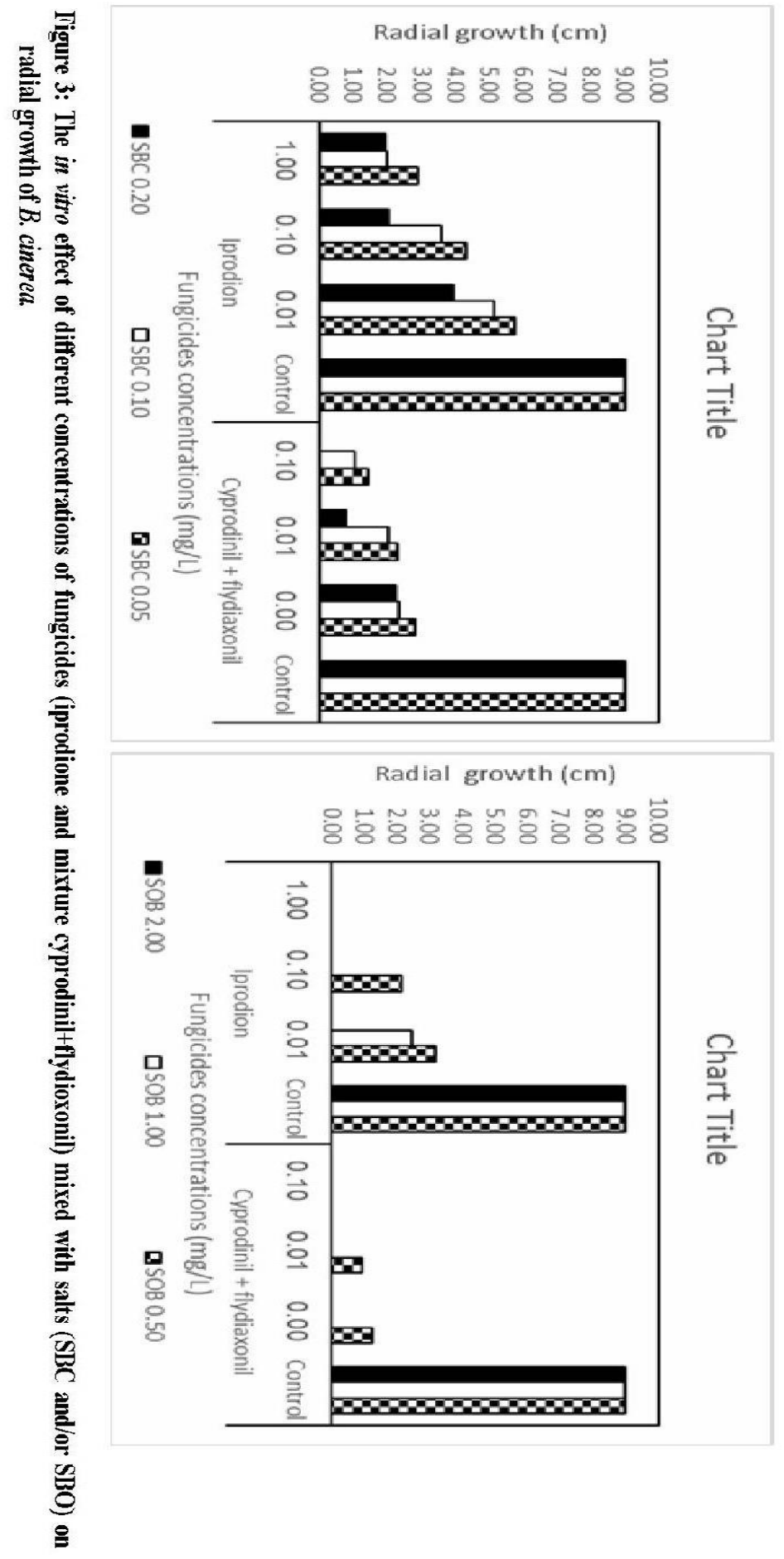


On the other hand, SBO at $2.0 \mathrm{~g} / 100 \mathrm{ml}$ mixed with iprodione at 1.00, 0.100 and $0.010 \mathrm{a} . \mathrm{i} \mathrm{mg} / \mathrm{L}$ and $\mathrm{SBO}$ at $1.0 \mathrm{~g} / 100 \mathrm{ml}$ mixed with iprodione at 1.00 and $0.10 \mathrm{mg} / \mathrm{L}$ in addition to $\mathrm{SBO}$ at $0.5 \mathrm{~g} / 100 \mathrm{ml}$ mixed with the same fungicide at $1.00 \mathrm{mg} / \mathrm{L}$ were the most effective and completely inhibited radial growth of $B$. cinerea, while the combinations of SBO at $1.0-0.5 \mathrm{~g} / 100 \mathrm{ml}$ with iprodione 0.10 and $0.01 \mathrm{mg} / \mathrm{L}$ resulted in radial growth ranged between $2.133 \mathrm{~cm}$ and $3.200 \mathrm{~cm}$, compared to $9.0 \mathrm{~cm}$ for the untreated control. However, SBO with mixture cyprodinil+flydioxonil combinations were more effective, where most treatments completely inhibited $B$. cinerea radial growth with the best treatment for 2.0 and $1.0 \%$ SBO with $0.1,0.01$ and 0.001 a.i $\mathrm{mg} / \mathrm{L}$ cyprodinil+flydioxonil fungicide, SBO $(0.5 \mathrm{~g} / 100 \mathrm{ml})$ mixed with $0.1 \mathrm{mg} / \mathrm{L}$ of the previous fungicide.

According to these results, it can be concluded that the highest concentration of SBO increased the efficacy of the least concentrations of fungicide in reducing the mycelial growth of $B$. cinerea (Table 2).The obtained results are in harmony with those mentioned by Zamani et al. (2008) and Helalia and Sameer (2014), who showed that the potency of the tested fungicides against Penicillium digitatum markedly increased by adding sodium bicarbonate imazalil had EC50 value of $0.148 \mu \mathrm{g} / \mathrm{ml}$ when used separately but recorded EC50 values of $0.08,0.053$ and $0.04 \mu \mathrm{g} / \mathrm{ml}$ and fungitoxic activity increments of $1.85,2.79$ and 3.70 folds when mixed with 1000 , 2000 and $3000 \mu \mathrm{g} / \mathrm{ml}$ sodium bicarbonate, respectively.

The results in Figure (4) summarized the activity of the tested salts with fungicides mixtures in reducing radial growth of $B$. cinerea. Significant reductions in radial growth were detected by SBC + iprodione or cyprodinil+flyudioxonil mixtures at the averages of 3.528 and $0.865 \mathrm{~cm}$, respectively. On the other hand, SBO mixed with cyprodinil+flyudioxonil had the highest effective inhibition of linear growth with an average of 0.321 $\mathrm{cm}$, compared with the other treatments. Generally, the fungicidal activity of the tested fungicides was increased by adding salts. These results were in agreement with those reported by other investigators (Smilanick et al., 2008, Dore et al., 2009, Montesinos-Herrero et al., 2011 and McKay et al., 2012).

\section{2- Field Experiments}

2.1. Effect of preharvest spray with certain salts and fungicides on controlling Botrytis fruit rot of strawberry:

Data in Table (3) showed that all treatments significantly decreased percentage of infection with Botrytis fruit rot on the stored strawberry fruits, harvested 1, 3, 7, 10 and 15 days after treatment, compared with the untreated control. However, there were insignificant differences in infection percentages among most of the tested treatments for fruits harvested 1 or 3 days after treatment and stored at $5^{\circ} \mathrm{C}$ for seven days. Fruits harvested after 7,10 and 15 days of treatment, the $50 \%$ cyprodinil+flydioxonil + SBC $2 \%$ treatment was the most effective where mean percentage of infection was as low as $4 \%$, compared to $23.867 \%$ for the untreated control. This was followed by $50 \%$ iprodione +SBC $2 \%$ treatment, $25 \%$ iprodione + SBC $2 \%, \quad 25 \%$ cyprodinil+flydioxonil $+\quad$ SBC $2 \%$, cyprodinil+flydioxonil alone and iprodione alone with percentages of infection being $7 \%, 8 \%, 8.5 \%$, $8.5 \%$, and $9 \%$, respectively, while treatment with SBC $2 \%$ showed the least infection level with $12.93 \%$ (Table 3). In this respect, Palou et al. (2001) and Smilanick et al. (2005) reported that sodium and ammonium bicarbonate inhibited fungal pathogens of fruits, field crops, vegetables and ornamentals and in addition, SBC applied at room temperature at 2 to $4 \%$ reduced blue mold caused by Penicillium italicum. Embaby et al. (2016) found that switch and Bio-Arc fungicides were better than others; they can reduce infection percentage of strawberry fruit decay caused by Alternaria $\mathrm{sp}, \mathrm{R}$. stolonifera and B. cinerea from 26.4 to $9.6 \%$.

Concerning the sodium benzoate (SBO) in combination with the tested fungicides, data in Table (4) showed that $50 \%$ cyprodinil+flydioxonil + SBO 2\%, 25\% cyprodinil+flydioxonil + SBO 2\% and $50 \%$ iprodione + SBO $2 \%$ treatments were the most effective, as mean percentages of fruit infection were as low as $3 \%, 4.5 \%$, and $6.43 \%$, respectively, compared to $23.86 \%$ for the untreated control. This was followed by cyprodinil+flydioxonil then; iprodione with $8.5 \%$, and $9.0 \%$ percentage of infection, respectively. However, SBO 2\%, and 25\% iprodione + SBO $2 \%$ showed the lowest effect with $17 \%$ and $19 \%$ mean percentage of infection, respectively, seven days after storage at $5^{\circ} \mathrm{C}$ (Table 4). The obtained results are in agreement with Adaskaveg et al. (2005), who evaluated potassium sorbate, SBO and other food additives should be evaluated in combination with low doses of the fungicide propiconazole (Menthor $45 \mathrm{WP}$, Syngenta) for their activity against sour rot as an additional strategy for managing postharvest application of this active ingredient and reducing the risk of proliferation of resistant strain of $\mathrm{G}$. candidum. The present findings are in harmony with those obtained by Palou et al. (2009), who reported that both incidence and severity of brown rot on summer fire nectarines wound inoculated with Monilinia fructicola and incubated at $20{ }^{\circ} \mathrm{C}$ for 5 days were reduced by about $100 \%$ after packing line application with a commercial CDA containing $20 \%$ fruit coating amended with half or full doses of fludioxonil and different mixtures of potassium sorbate, sodium benzoate, or 2-deoxy-D-glucose. 


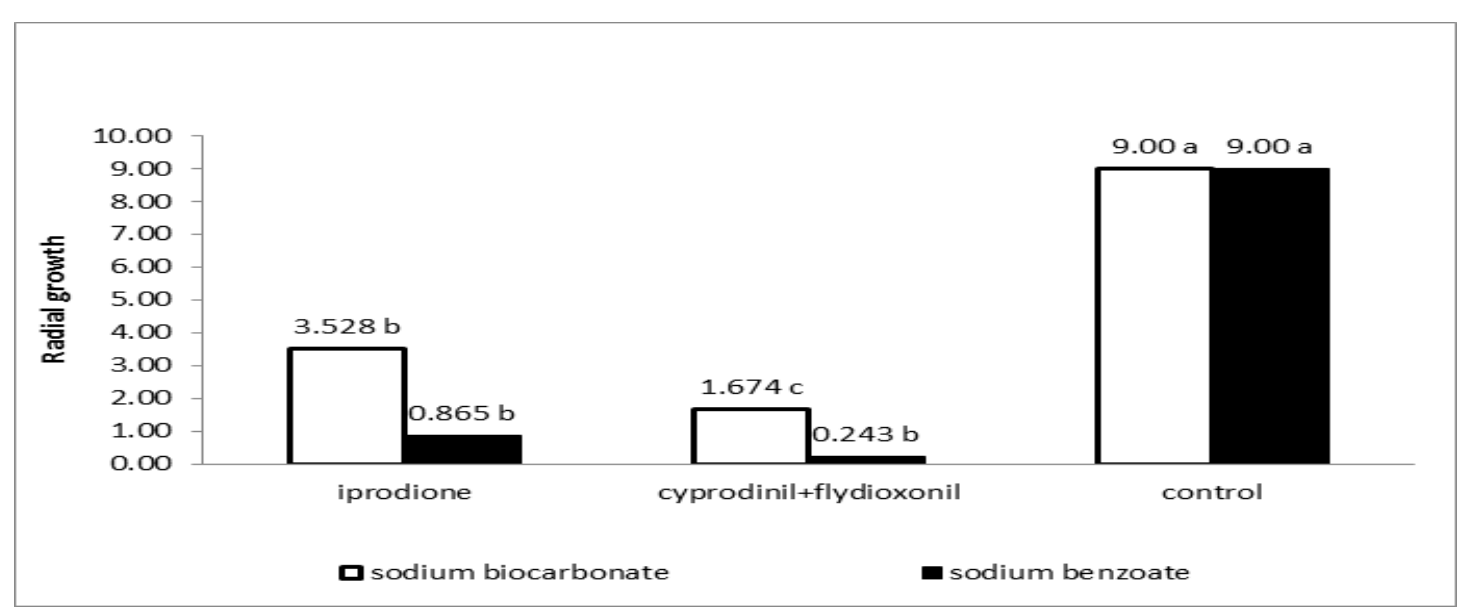

Figure 4: The in vitro effect of fungicides combined with salts on radial growth of $B$. cinerea

Table 3: Effect of pre-harvest treatments with iprodione or cyprodinil+flydioxonil fungicides alone or their mixture with SBC on percentage of infection with gray mould of strawberry (cv. Festival) on fruits harvested at different periods after treatment and stored at $5{ }^{\circ} \mathrm{C}$ for seven days.

\begin{tabular}{lllllll}
\hline \multirow{2}{*}{ Treatment } & \multicolumn{5}{c}{$\begin{array}{c}\text { Percentage of fruit infection } \\
\text { \& Days after treatment }\end{array}$} \\
\cline { 2 - 7 } & 1 Day & 3 Day & 7 Day & 10 Day & 15 Day & Mean \\
\hline iprodione alone & $0.00 \mathrm{~b}$ & $2.50 \mathrm{~b}$ & $7.50 \mathrm{c}$ & $17.50 \mathrm{bc}$ & $17.50 \mathrm{~d}$ & $9.00 \mathrm{~cd}$ \\
\hline $50 \%$ iprodione +SBC 2\% & $0.00 \mathrm{~b}$ & $0.00 \mathrm{c}$ & $2.50 \mathrm{e}$ & $10.00 \mathrm{e}$ & $22.50 \mathrm{~cd}$ & $7.00 \mathrm{e}$ \\
\hline 25\% iprodione + SBC 2\% & $0.00 \mathrm{~b}$ & $0.00 \mathrm{c}$ & $5.00 \mathrm{~d}$ & $10.00 \mathrm{e}$ & $25.00 \mathrm{c}$ & $8.00 \mathrm{de}$ \\
\hline cyprodinil+flydioxonil alone & $0.00 \mathrm{~b}$ & $0.00 \mathrm{c}$ & $10.00 \mathrm{~b}$ & $15.00 \mathrm{de}$ & $17.50 \mathrm{c}$ & $8.50 \mathrm{c}$ \\
\hline $25 \%$ cyprodinil+flydioxonil + SBC 2\% & $0.00 \mathrm{~b}$ & $0.00 \mathrm{c}$ & $5.00 \mathrm{~d}$ & $5.00 \mathrm{f}$ & $10.00 \mathrm{e}$ & $4.00 \mathrm{f}$ \\
\hline SBC 2\% & $0.00 \mathrm{~b}$ & $0.00 \mathrm{c}$ & $10.00 \mathrm{~b}$ & $15.00 \mathrm{~cd}$ & $17.500 \mathrm{~d}$ & $8.50 \mathrm{c}$ \\
\hline Control (sprayed with tap water) & $0.00 \mathrm{~b}$ & $2.50 \mathrm{~b}$ & $7.50 \mathrm{c}$ & $14.66 \mathrm{~d}$ & $40.00 \mathrm{~b}$ & $12.93 \mathrm{~b}$ \\
\hline LSD 5\% & $2.50 \mathrm{a}$ & $7.50 \mathrm{a}$ & $15.00 \mathrm{a}$ & $32.50 \mathrm{a}$ & $61.83 \mathrm{a}$ & $23.86 \mathrm{a}$ \\
\hline (Mean) & 0.278 & 0.816 & 1.244 & 2.595 & 5.168 & 1.890 \\
\hline SBC sodinil+flydioxonil + SBC 2\% & $0.313 \mathrm{D}$ & $1.56 \mathrm{D}$ & $7.81 \mathrm{C}$ & $14.95 \mathrm{~B}$ & $26.479 \mathrm{~A}$ & \\
\hline
\end{tabular}

$\overline{\mathrm{SBC}}$, sodium bicarbonate, $50 \%=45.0$ to iprodione and 37.5 to cyprodinil+flydioxonil $\mathrm{mg} / \mathrm{L}, 25 \%=22,5$ to iprodione and 18.75 to cyprodinil+flydioxonil $\mathrm{mg} / \mathrm{L}$

Values followed by different letter(S), for each parameter, are significantly different at 0.05 of probability.

Table 4: Effect of pre-harvest treatments with iprodione or cyprodinil+flydioxonil fungicides alone or their mixture with sodium benzoate on percentage of infection with gray mould of strawberry (cv. Festival) on fruits harvested at different periods after treatment and stored at $5{ }^{\circ} \mathrm{C}$ for seven days.

\begin{tabular}{lcccccc}
\hline \multirow{2}{*}{ Treatment } & \multicolumn{5}{c}{ Percentage of fruit infection \& Days after treatments } \\
\cline { 2 - 7 } & 1 Day & 3 Day & 7 Day & 10 Day & 15 Day & Mean \\
\hline iprodione & $0.00 \mathrm{~b}$ & $2.50 \mathrm{~b}$ & $7.50 \mathrm{~d}$ & $17.50 \mathrm{c}$ & $17.50 \mathrm{~b}$ & $9.00 \mathrm{c}$ \\
\hline $50 \%$ iprodione +SBO 2\% & $0.00 \mathrm{~b}$ & $0.00 \mathrm{c}$ & $2.50 \mathrm{e}$ & $9.66 \mathrm{~d}$ & $20.00 \mathrm{~b}$ & $6.43 \mathrm{de}$ \\
\hline $25 \%$ iprodione + SBO 2\% & $0.00 \mathrm{~b}$ & $2.50 \mathrm{~b}$ & $12.50 \mathrm{~b}$ & $22.50 \mathrm{~b}$ & $57.50 \mathrm{a}$ & $19.00 \mathrm{~b}$ \\
\hline cyprodinil+flydioxonil & $0.00 \mathrm{~b}$ & $0.00 \mathrm{c}$ & $10.00 \mathrm{c}$ & $15.00 \mathrm{c}$ & $17.50 \mathrm{~b}$ & $8.50 \mathrm{~cd}$ \\
\hline $50 \%$ cyprodinil+flydioxonil + SBO 2\% & $0.00 \mathrm{~b}$ & $0.00 \mathrm{c}$ & $0.00 \mathrm{f}$ & $2.50 \mathrm{e}$ & $12.50 \mathrm{c}$ & $3.00 \mathrm{f}$ \\
\hline $25 \%$ cyprodinil+flydioxonil + SBO 2\% & $0.00 \mathrm{~b}$ & $0.00 \mathrm{c}$ & $0.00 \mathrm{f}$ & $5.00 \mathrm{e}$ & $17.50 \mathrm{~b}$ & $4.50 \mathrm{ef}$ \\
\hline SBO 2\% & $0.00 \mathrm{~b}$ & $0.00 \mathrm{c}$ & $7.50 \mathrm{~d}$ & $22.50 \mathrm{~b}$ & $57.50 \mathrm{a}$ & $17.50 \mathrm{~b}$ \\
\hline Control sprayed with tap water & $2.50 \mathrm{a}$ & $7.50 \mathrm{a}$ & $15.00 \mathrm{a}$ & $32.50 \mathrm{a}$ & $61.83 \mathrm{a}$ & $23.86 \mathrm{a}$ \\
\hline LSD 5\% & 0.278 & 0.834 & 1.781 & 3.159 & 6.862 & 2.395 \\
\hline Mean & $0.313 \mathrm{D}$ & $1.563 \mathrm{D}$ & $6.875 \mathrm{C}$ & $15.896 \mathrm{~B}$ & $32.729 \mathrm{~A}$ & \\
\hline SBO, s0d
\end{tabular}

$\overline{\mathrm{SBO}}$, sodium benzoate, $50 \%=45.0$ to iprodione and 37.5 to cyprodinil+flydioxonil $\mathrm{mg} / \mathrm{L}, 25 \%=22,5$ to iprodione and 18.75 to cyprodinil+flydioxonil $\mathrm{mg} / \mathrm{L}$

Values followed by different letter(S), for each parameter, are significantly different at 0.05 of probability. 
2.2. Correlation between postharvest botrytis fruit rot incidence and harvest interval after treatments.

Positive strong correlations coefficient $(r=0.943-0.981)$ were depicted between postharvest Botrytis fruit rot increase and harvest intervals. The strength of these relationships were shown again in the sharpness of the regression slops were revealed between postharvest botrytis fruit rot incidence and harvest interval periods, as increasing harvest interval periods increased percentage of natural infection of strawberry fruit with botrytis gray mould (Figure 5).

2.3-Effect of the field salt and fungicide treatments on enzymes activity of strawberry fruits after storage.

Data illustrated in Figure 6 (a, b, c and d) showed the effect of field application with sodium bicarbonate (SBC) or sodium benzoate (SBO), iprodione and cyprodinil+fludioxonil fungicides singly or in combination, on pectinase (PC) and celluloses (CX) activity of strawberry fruits harvested at different periods after treatments and stored at $5^{\circ} \mathrm{C}$ for seven days. It is evident that obvious increase in $\mathrm{PC}$ and $\mathrm{Cx}$ activities were revealed in fruits harvested after 10 and 15 days of salt and fungicide preharvest treatments and stored for 7 days at $5{ }^{\circ} \mathrm{C}$. Meanwhile, considerable lowest activities were recorded for the tested enzymes in fruits harvested 1,3 and 7 days after preharvest treatments and stored for 7 days at $5^{\circ} \mathrm{C}$.

Increases in the activity levels of pectolytic and cellulytic enzymes associated with fruit rots, incited by B. cinerea were reported by several investigators in strawberry (Berto et al., 2001, Brummell et al., 2002 and El-Habbaa, 2003).
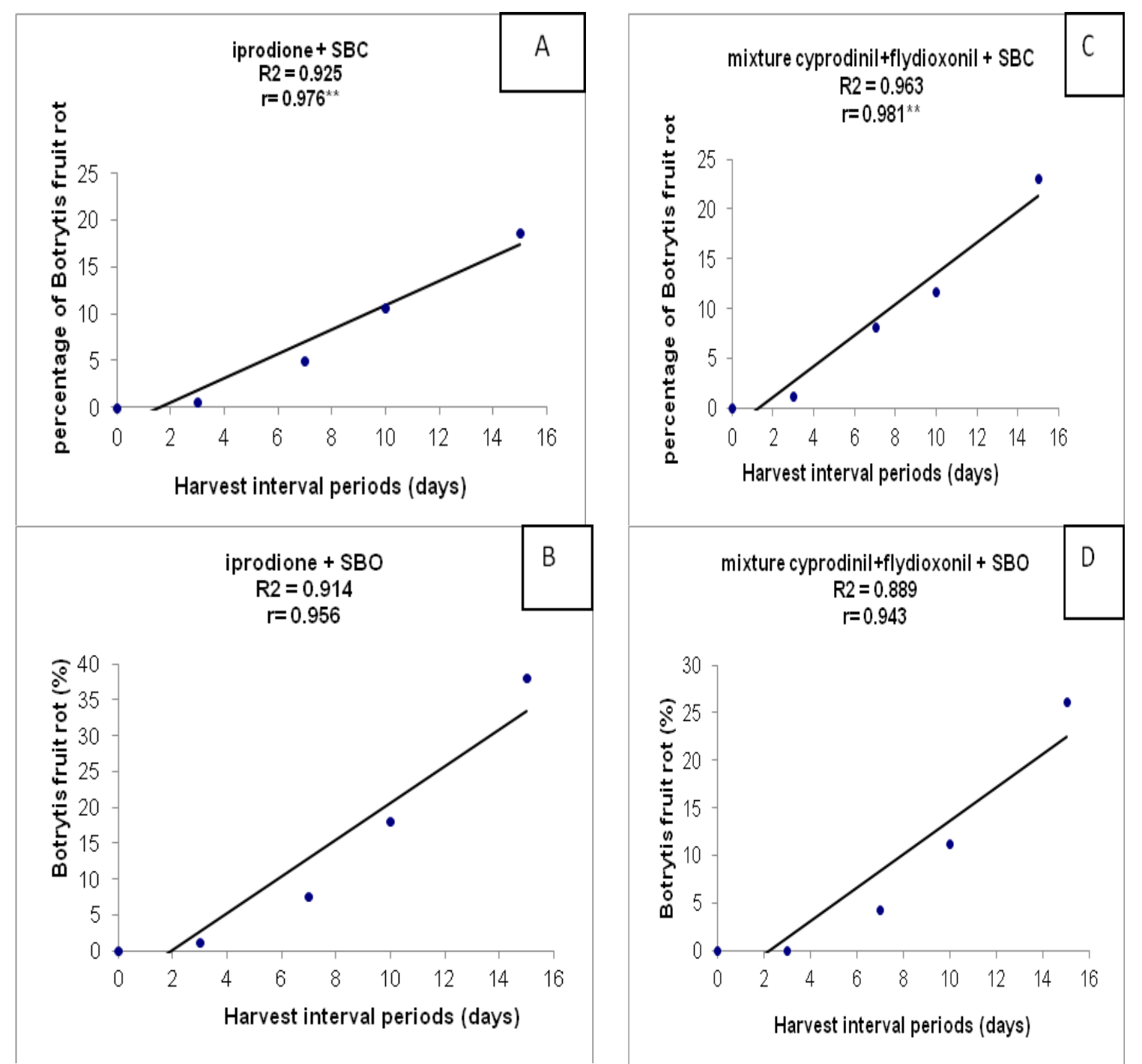

Figure 5: Correlation between harvest intervals, after treatments with two salts and iprodione and cyprodinil+fludioxonil fungicides, and percentage of infection with Botrytis fruit rot developed in strawberry fruits stored at $5 \mathrm{C}$ for seven days 


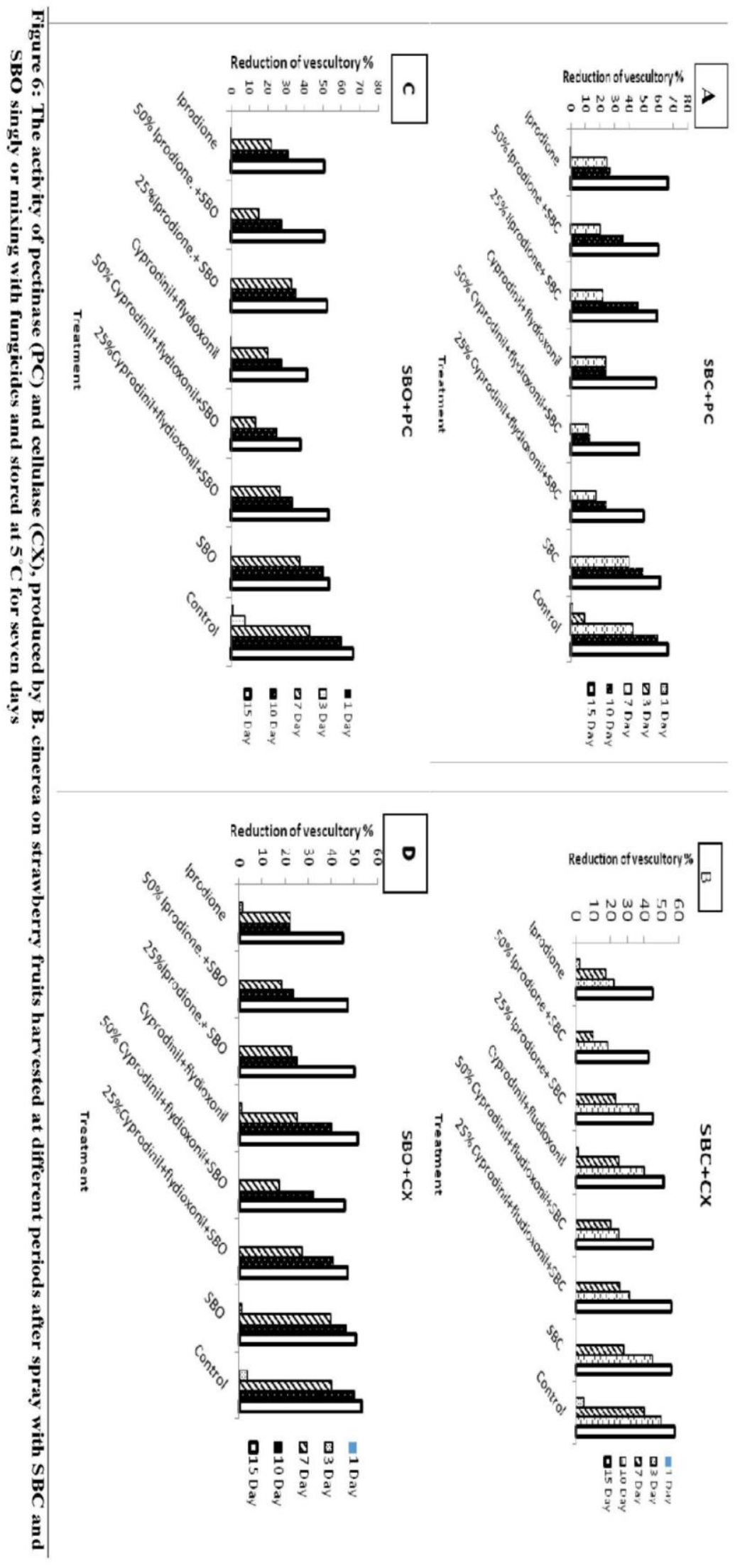




\subsection{Degradation of fungicidal residues:}

Data in Table (5) showed that residues of all tested fungicides in treated strawberry fruits decreased with decreasing percentage of the fungicide in the salt+fungicide mixture. cyprodinil $25 \%+\mathrm{SBO}$, and cyprodinil $25 \%+\mathrm{SBC}$ treatments exhibited the lowest residue values being 1.420 and $1.680 \mathrm{mg} / \mathrm{kg}$ fruit one hour after treatment, while iprodione $25 \%+$ SBO, and iprodione $25 \%+$ SBC showed 8.430 and $9.650 \mathrm{mg} / \mathrm{kg}$ fruit, respectively. However, iprodione $100 \%$, cyprodinil $100 \%$, flydioxonil $100 \%$ showed the highest residue values being $29.810,8.400,7.300 \mathrm{mg} / \mathrm{kg}$ fruit, respectively. Also, residues decreased with increasing time after preharvest application with fungicides and storage for seven days at $5^{\circ} \mathrm{C}$ where fruits harvested after 15 days and stored for 7 days at $5^{\circ} \mathrm{C}$ showed the lowest residue values for all treatments. Generally, iprodione treatments showed the highest fungicidal residues, followed by cyprodinil and flydioxonil (Table 5 and figure 7). However, addition of any of the two salts to any of the tested fungicides did reduce the residue values compared to the single fungicide.

On the other hand, a strong negative correlations were revealed between time after treatment and residues in strawberry fruits of the three fungicides with $r=0.976, r=0.949$, and $r=0.946$, for iprodione, cyprodinil, and flydioxonil, respectively (Figure 8). The obtained results are in agreement with Abada et.al (2005) as indicated that residues of the fungicides in the harvested fruits gradually decreased by increasing the intervals after spraying.

Consequently, as the use of fungicides is still an important component of any integrated pest management program (IPM) as the last resort, search for more effective fungicides at low concentrations and lower number of application with the aid of such salt applications is conducted and approved in the present study for a safer control of postharvest gray mold of strawberry caused by $B$. cinerea. However, effect of such salts on market proprieties of fruits and their physical and chemical characteristics and acidity is still in need for further studies indeed.

Table 5: Fungicide residues in strawberry fruits sprayed preharvest with flydioxonil, cyprodinil and iprodione fungicides individually or in combination with sodium bicarbonate or sodium benzoate and harvested at different intervals after treatment and stored at $5^{\circ} \mathrm{C}$ for seven days.

\begin{tabular}{|c|c|c|c|c|c|c|c|}
\hline \multirow[t]{2}{*}{ Treatments } & \multicolumn{7}{|c|}{$\begin{array}{c}\text { Residue in } \mathrm{mg} / \mathrm{kg} \text { fruits } \\
\text { Time harvest after treatment (days) }\end{array}$} \\
\hline & initial & 1 day & 3days & 7days & 10days & 15days & Mean \pm SE \\
\hline flydioxonil (100\%) & $7.300 \mathrm{de}$ & $6.200 \mathrm{cde}$ & $3.800 \mathrm{de}$ & $2.200 \mathrm{fg}$ & $1.300 \mathrm{f}$ & $0.050 \mathrm{e}$ & 3.475 ef \pm 0.473 \\
\hline flydioxonil $(50 \%)+$ SBC & $6.440 \mathrm{e}$ & $5.270 \mathrm{de}$ & $3.360 \mathrm{e}$ & $1.850 \mathrm{f}-\mathrm{i}$ & $1.120 \mathrm{f}$ & $0.042 \mathrm{e}$ & $3.014 \mathrm{f} \pm 0.413$ \\
\hline Flydioxonil $(25 \%)+$ SBC & $2.040 \mathrm{f}$ & $1.670 \mathrm{f}$ & $0.950 \mathrm{f}$ & $0.640 \mathrm{~g}-\mathrm{j}$ & $0.377 \mathrm{f}$ & $0.014 \mathrm{e}$ & $0.949 \mathrm{~g} \pm 0.129$ \\
\hline flydioxonil(50\%) SBO & $6.160 \mathrm{e}$ & $5.010 \mathrm{e}$ & $3.020 \mathrm{e}$ & $1.610 \mathrm{f}-\mathrm{j}$ & $0.920 \mathrm{f}$ & $0.038 \mathrm{e}$ & $2.793 \mathrm{f} \pm 0.400$ \\
\hline flydioxonil $(25 \%)+$ SBO & $2.010 \mathrm{f}$ & $1.360 \mathrm{f}$ & $0.820 \mathrm{f}$ & $0.530 \mathrm{~h}-\mathrm{j}$ & $0.260 \mathrm{f}$ & $0.003 \mathrm{e}$ & $0.831 \mathrm{~g} \pm 0.124$ \\
\hline cyprodinil $(100 \%)$ & $8.400 \mathrm{~cd}$ & $6.800 \mathrm{~cd}$ & $4.550 \mathrm{cde}$ & $2.560 \mathrm{ef}$ & $1.320 \mathrm{f}$ & $0.040 \mathrm{e}$ & 3.945 ef \pm 0.540 \\
\hline cyprodinil $(50 \%)+\mathrm{SBC}$ & $6.720 \mathrm{de}$ & $5.060 \mathrm{e}$ & $3.370 \mathrm{e}$ & $1.740 \mathrm{f}-\mathrm{j}$ & $1.150 \mathrm{f}$ & $0.042 \mathrm{e}$ & $3.014 \mathrm{f} \pm 0.421$ \\
\hline cyprodinil $(25 \%)+\mathrm{SBC}$ & $1.680 \mathrm{f}$ & $1.360 \mathrm{f}$ & $1.070 \mathrm{f}$ & $0.440 \mathrm{ij}$ & $0.340 \mathrm{f}$ & $0.011 \mathrm{e}$ & $0.817 \mathrm{~g} \pm 0.109$ \\
\hline cyprodinil $(50 \%)+$ SBO & $6.410 \mathrm{e}$ & $5.210 \mathrm{de}$ & $3.120 \mathrm{e}$ & $1.530 \mathrm{f}-\mathrm{j}$ & $1.040 \mathrm{f}$ & $0.030 \mathrm{e}$ & $2.890 \mathrm{f} \pm 0.417$ \\
\hline cyprodinil $(25 \%)+\mathrm{SBO}$ & $1.420 \mathrm{f}$ & $1.020 \mathrm{f}$ & $0.970 \mathrm{f}$ & $0.210 \mathrm{j}$ & $0.060 \mathrm{f}$ & $0.010 \mathrm{e}$ & $0.615 \mathrm{~g} \pm 0.099$ \\
\hline iprodione $(100 \%)$ & $29.810 \mathrm{a}$ & $27.130 \mathrm{a}$ & $25.410 \mathrm{a}$ & $23.670 \mathrm{a}$ & $21.220 \mathrm{a}$ & $15.020 \mathrm{~b}$ & $23.710 \mathrm{a} \pm 0.861$ \\
\hline iprodione $(50 \%)+\mathrm{SBC}$ & $24.740 \mathrm{~b}$ & $23.150 \mathrm{~b}$ & $21.010 \mathrm{~b}$ & $20.590 \mathrm{~b}$ & $18.880 \mathrm{~b}$ & $16.160 \mathrm{~b}$ & $20.755 b \pm 0.507$ \\
\hline iprodione $(25 \%)+\mathrm{SBC}$ & $9.650 \mathrm{c}$ & $7.330 \mathrm{c}$ & $6.020 \mathrm{c}$ & $5.320 \mathrm{~d}$ & $4.920 \mathrm{~d}$ & $3.150 \mathrm{~d}$ & $6.065 \mathrm{~d} \pm 0.371$ \\
\hline iprodione $(50 \%)+\mathrm{SBO}$ & $23.260 \mathrm{~b}$ & $22.030 \mathrm{~b}$ & $19.920 \mathrm{~b}$ & $17.350 \mathrm{c}$ & $16.280 \mathrm{c}$ & $13.000 \mathrm{c}$ & $18.640 \mathrm{c} \pm 0.639$ \\
\hline iprodione $(25 \%)+\mathrm{SBO}$ & $8.430 \mathrm{~cd}$ & 6.250 cde & $5.330 \mathrm{~cd}$ & $4.110 \mathrm{de}$ & $3.030 \mathrm{e}$ & $2.550 \mathrm{~d}$ & $4.950 \mathrm{de} \pm 0.366$ \\
\hline LSD 5\% & 1.737 & 1.644 & 1.592 & 1.557 & 1.449 & 1.218 & 1.627 \\
\hline Time mean $\pm \mathrm{SE}$ & $\begin{array}{l}10.538^{\mathrm{a}} \\
\pm 3.150 \\
\end{array}$ & $\begin{array}{ll}9.12 \mathrm{~b} \quad \pm \\
2.98 & \\
\end{array}$ & $\begin{array}{ll}7.57 \mathrm{c} \quad \pm \\
2.88 & \\
\end{array}$ & $\begin{array}{l}6.25 \mathrm{~d} \pm \\
2.83\end{array}$ & $\begin{array}{l}5.323 \mathrm{e} \pm \\
2.628\end{array}$ & $\begin{array}{r}3.809 \mathrm{f} \\
\pm 2.209 \\
\end{array}$ & 0.724 \\
\hline
\end{tabular}

Values followed by different letter(S), for each parameter, are significantly different at 0.05 of probability. 


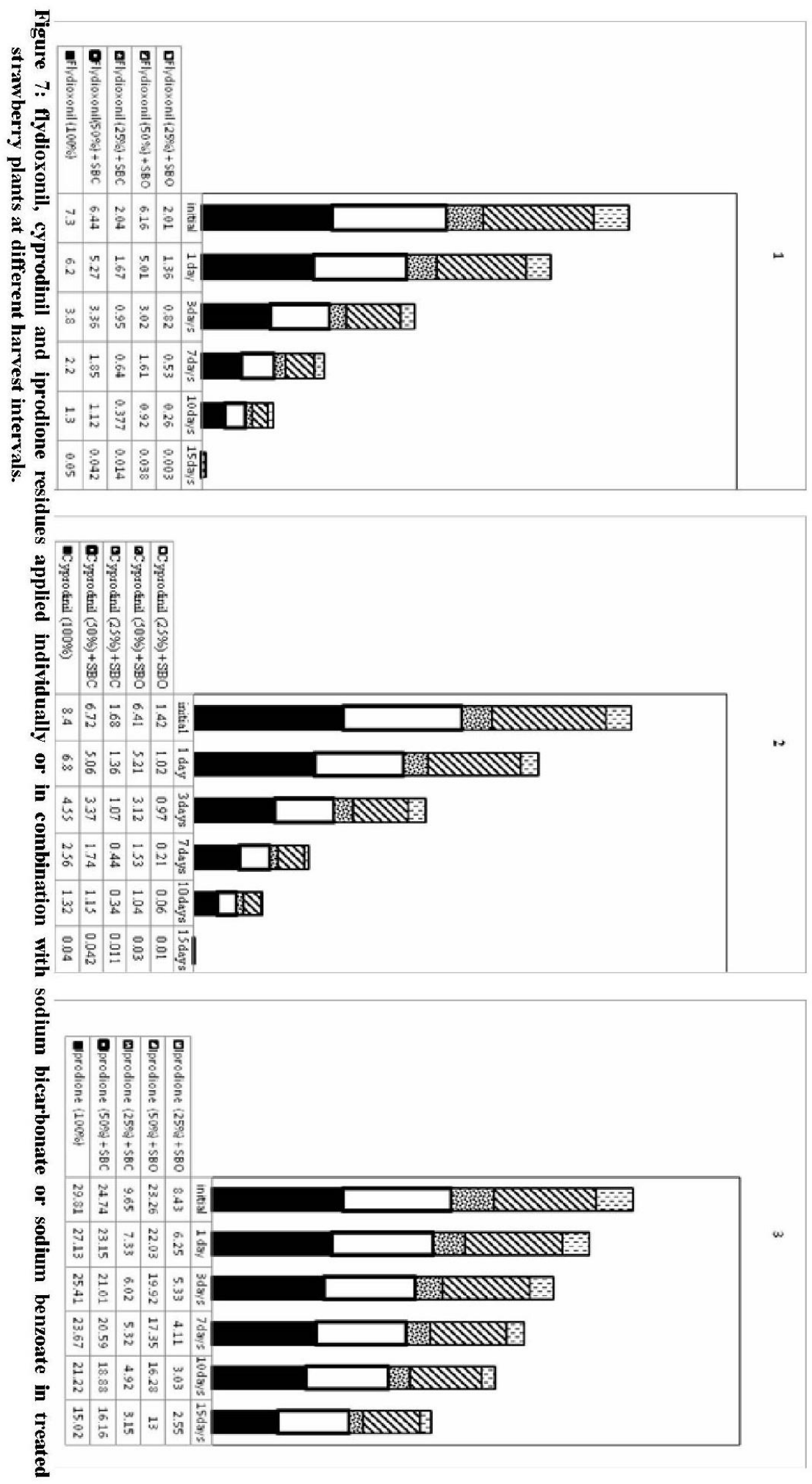




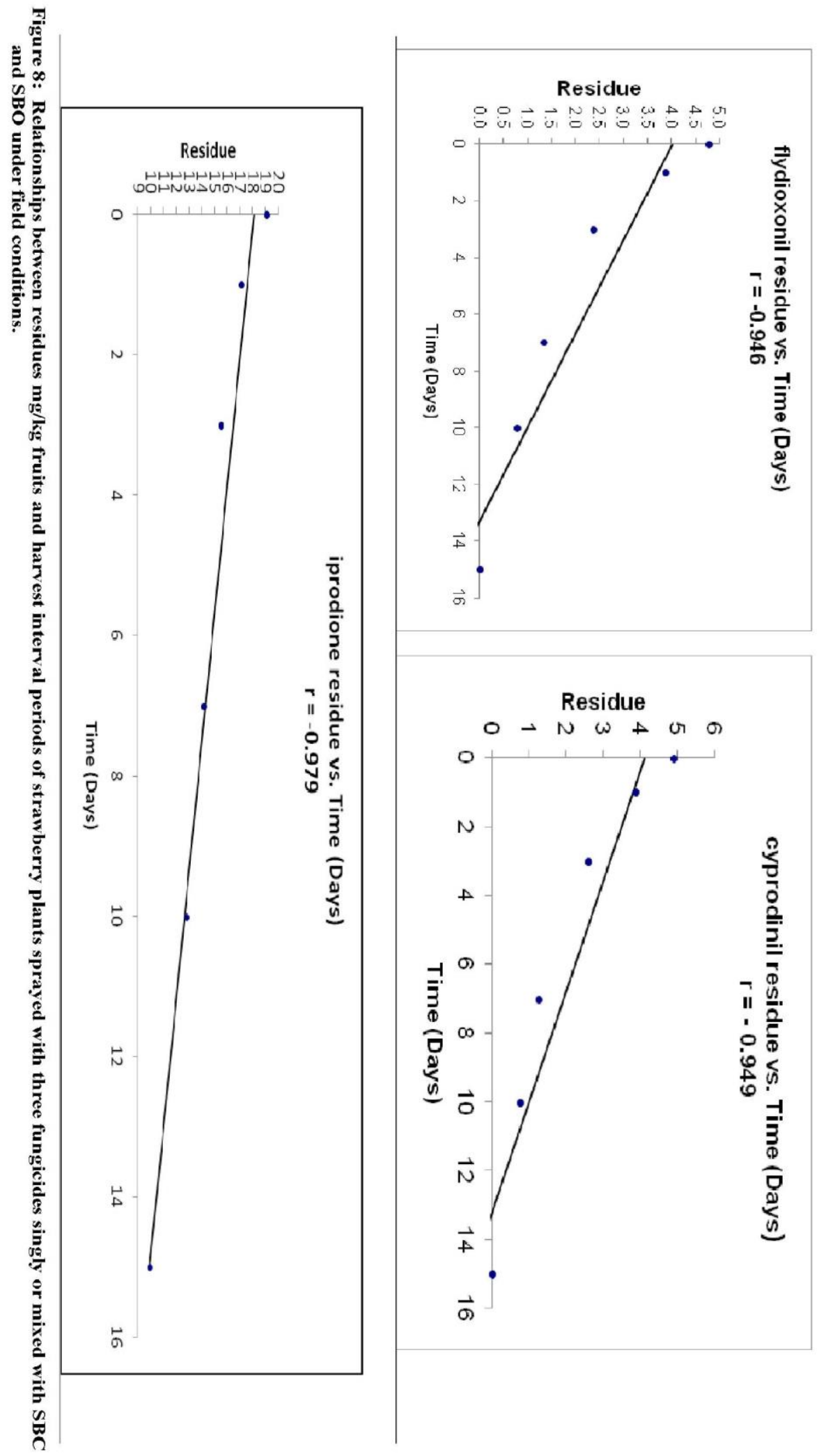




\section{REFERENCES}

Abada, K. A., Mostafa, M.A., Dogheim, Salwa M.A. and Gomaa, A.M.I. (2005). Control of strawberry fruit rots by Fungicides and Determination of their Residues in the Harvested Fruits. Egypt. J. Phytopathol., 33: 83-92.

Adaskaveg, J.E., Fö rster, H., Gubler, W.D., Teviotdale, B.L. and. Thompson, D. F (2005). Reduced-risk fungicides help manage brown rot and other fungal diseases of stone fruit. Calif Agric. 59: 109-114.

AOAC, 1995. Official Method of Analysis. 16th Ed. Barakat, R.M. and Al-Masri, M.I. (2017). Effect of Trichoderma harzianum in combination with fungicides in controlling gray mould disease (Botrytis cinerea) of strawberry. American J. of Plant Sciences, 8: 651-665.

Barnett, H. L. and Hunter, B. (1972). Illustrated genera of imperfect fungi. Burgess publishing company, USA. 241pp.

Bell; T.A., Etchell, J.L. and Jones, I.D. (1955). A method for testing cucumber salt stock brine for softening activity. U, S. Dept. Agric., A.R.S., 72: (c.f Phytopathology, 53: 197).

Berto, P, Jijakli, M.H. and Lepoivre, P. (2001). Possible role of colonization and cell walldegrading enzymes in the differential ability of three strains to control Botrytis cinerea on necrotic strawberry leaves. Phytopathology, 91: 1030 - 1036.

Blacharski, R.W., Bartz, J.A., Xiao, C.L. and Legard, D.E. (2001). Control of postharvest Botrytis fruit rot with preharvest fungicide applications in annual strawberry. Plant Dis., 85: 597-602.

Brummell, D.A., Howie, W.J., Ma, C. and Dunsmuir, P. (2002). Postharvest fruit quality of transgenic tomatoes suppressed in expression of a ripening-related expansion. Postharvest Biology and Technology, 25: 209220.

Costat, Cohort Software Inc. (1985). Costat User Manual, Version 3, CohortTucson. Arizona, USA.

Dore, A., Molinu, G. M., Venditti, T., Petretto, A. and Hallewin G.D. (2009). Host involvement in the improved decay control following $\mathrm{NaHCO}_{3}$ co-application with imazalil. Commun. Agric. Appl. Biol. Sci., 74:715-712.

Droby, S. and Lichter, A. (2004). Postharvest Botrytis infection: Etiology, development and management. In: Elad, Y.; Williamson, B; Tudzyski, P.;Delen, N. (Eds.), Botrytis: Biology, Pathology and Control. Kluwer Academic Publishers, Dordrecht, The Netherland, 349-367.
Droby, S., Wisniewski M., El-Ghaouth A. and Wilson C. (2003). Influence of food additives on the control of postharvest rots of apple and peach and efficacy of the yeast-based biocontrol product Aspire. Postharvest Biol. Technol., 27:127-135.

El-Gamal, Nadia G., El-Mougy, Nehal S., M.M. Abdel-Kader and R.S. EL- Mohamady (2014). Integration between yeast and some organic salts treatments for controlling tomato fruits decay. Int. J. of Eng. and Innov. Techol., 4: 33-39.

El-Habbaa, G.M. (2003). Polygalacturonase isozymes and cell wall degrading enzymes secreted by $B$. cinerea the causal of grey mould disease on vegetables. Egyptian Journal of Phytopathology, 31: 87-101.

El-Mougy, Nehal S., El-Gamal, Nadia G, AbdelKader M.M. and Abd-Elgawad M.M.M. (2015). Integrated Field Approaches of Yeast and Some Food Preservatives Treatments for Controlling Postharvest Green and Blue Molds of Eureka. Int. J. of Eng. and Innov. Techol., 4: 262-266.

Embaby, E.M., Abdel-Galil, Mona M., and Aiat, Nahed M. (2016). Control strawberry fruit decay caused by some mold fungi. International Journal of Pharm Tech Research 9: 184-193

Fayza T. A., L. Askarne, H. Boubaker, E. Boudyach, A. Ait and B. Aoumar (2017). Control of Gray Mold Disease of Tomato by Postharvest Application of Organic Acids and Salts. Plant Pathol. J.,16 (2): 62-72

Gilman, C. J. (1957): A Manual of Soil Fungi. 2nd Iowa State College. Press, USA, $450 \mathrm{pp}$.

Gomez, K.A. and Gomez, A.A. (1984). Statistical procedures for Agricultural Research. $\left(2^{\text {nd }} \mathrm{ed}\right)$. An International Rice Research Institute J. Wiley and Sons, New York, USA. pp. 377434.

Haydu, J.J. (2003). An economic analysis of preharvest fungicide applications to control Botrytis Fruit rot in annual strawberries in Florida Hort Science. 38 (1): 124-127.

Helalia, A.R. and Sameer, W.M. (2014). Efficacy of fungicides - sodium bicarbonate combinations on citrus postharvest green mould disease. Mid. East J. of Agric. Res., 3(2): 194-200.

Hongyin, Z., Lei, W.; Ying, D., Song, J., Jian, C. and M. Ruji (2007). Postharvest control of gray mold decay of strawberry with Rhodotorula glutinis. Biological Control 40: 287-292. 
Ippolito, A., Nigro, F. and de Cicco, V. (2005). Natural antimicrobials for preserving fresh fruit and vegetables in: improving the safety of fresh fruit and vegetables, Jongen, W. (Ed.). Chapter 17, Woodhead Publishing, Cambridge, UK., ISBN-13: 9781845690243 , pp: 513-555.

Luke, M.M., Froberge, J.E., Doose, G.M. and Masumoto, H.T. (1981). Improved multiresidue gas chromatographic determination of organophosphorus of organophosphorus, organonitrogen and organohalogen pesticides, using flam photometric and electrolytic conductivity detectors. J. Asso. of Anal. Chem. 64: 11871195.

McKay, A.H., Forster, H. and Adaskaveg, J.E. (2012). Efficacy and application strategies for propiconazole as a new postharvest fungicide for managing sour rot and green mold of citrus fruit. Plant Dis., 96: 235-242.

Melanie R. M., Arul, J. and Tweddell, R. J. (2002). Effect of organic and inorganic salts on the growth and development of Fusarium sambucinum, a Causal agent of potato dry rot. Mycological Research.106:688-696.

Menzel, C.M.; Gomez, A. and Chen, H. (2016). Control of Grey Mould and Stem-End Rot in Strawberry Plants Growing in a Subtropical Environment. Australian Plant Pathology, 45: 489-498.

Mills, A.A.S., Platt, H.W. and Hurta, R.A.R. (2004). Effect of salt compounds on mycelial growth, sporulation and spore germination of various potato pathogens. Postharvest Biol. Technol., 34: 341-350.

Montesinos-Herrero, C., Smilanick, J.L., Tebbets, J.S., Walse, S. and Palou, L. (2011). Control of citrus postharvest decay by ammonia gas fumigation and its influence on the efficacy of the fungicide imazalil. Postharvest Biology and Technology, 59: 85-93.

Nigro F, Schena, L.; Ligorio, A., Pentimone, I., Ippolito, A. and Salerno, M.G. (2006) Control of table grapes storage rots by preharvest applications of salts. Postharvest Biology and Technology. 42(2):142-149.

Oliver,C.; Mac Neil, C. R., and loria, R. (1999). Application of organic and Inorganic salts to field-grown potato tubers can suppress silver scurf during

Potato storage. Plant Dis. 83: (9) 1462-2468

Palmer CL., Horst, RK., Langhans, RW. (1997) Use of bicarbonates to inhibit in vitro growth of (Botrytis cinerea). Plant Dis. 81:1432-1438.
Palou, L., Smilanick, J. L. and Crisosto, C.H. (2009). Evaluation of food additives as alternative or complementary chemicals to conventional fungicides for the control of major postharvest diseases of stone fruit. Journal of Food Protection, 72: 1037-1046.

Palou, L., Smilanick, J.I., Usall, J. and Vinas, L. (2001). Control of postharvest blue and green molds of oranges by hot water, sodium carbonate and sodium bicarbonate. Plant Dis., 85: 371-376.

Pankaj, R. and Singh, R. P. (2017). Evaluation of fungicides against gray mould (Botrytis cinerea Pers. Fr) and Leaf mould [Fulvia fulva (Cooke) Cif.(Cladosporium fulvum Cooke) of tomato. Int. J. of Chemical Studies 5: 400-404

Sabebaro N.D., Sarma, T.C. and Tapadar, S. A. (2014). In vitro evaluation of fungicides and two species of Trichoderma against Phomopsis vexans causing fruits rot of bringal (Salanum melongena L.). Int. J. of Sci. Res. Publication 4 (9): 1-3.

Sanzani, S.M., Nigro, F.; Mari, M. and Ippolito, A. (2009). innovations in the control of postharvest diseases of fresh fruits and vegetables. Arab J. of Plant Protec. 27:240244.

Sesan, T.F. (2003). Sustainable management of gray mould (Botrytis cinerea) on grapevine, strawberry and ornamentals. In: Chapter in advances in plant management. Huang. H.C., Surya A. (eds.). Res. Signpost publ. House, 121-152.

Smilanick, J. L., Mansour, M.F., Gabler, F.M. and Sorenson, D. (2008). Control of citrus postharvest green mold and sour rot by potassium sorbate combined with heat and fungicides. Postharvest Biol. Technol., 47: 226-238

Smilanick, J.L., Margosan D.A., Mlikota, F., Usall, J. and Michael, I. F. (1999). Control of citrus green mold by carbonate and bicarbonate salts and the influence of commercial postharvest practices on their efficacy. Plant Dis. 83: 139145.

Smilanick, J.L., Mansour, M.F., Margosan, D. A., Gabler, F. M. and Goodwine, W.R. (2005). Influence of $\mathrm{pH}$ and $\mathrm{NaHCO} 3$ on effectiveness of imazalil to inhibit germination of Penicillium digitatum and to control postharvest green mold on citrus fruit. Plant Disease. 89: 640-648.

Talboys, P. W. and Busch, L.V. (1970). Pectic enzymes produced by Verticilum spp. Trans. Brit. Mycol. Soc., 55: 367-381. 
Wan, Y.K., Tian, S.P. and Qin, G.Z. (2003). Enhancement of biocontrol activity of yeasts by adding sodium bicarbonate or ammonium molybdate to control postharvest disease of jujube fruits. Lett. Applied Microbiol., 37: 249-253.

Williamson, B., Tudzynski, B., Tudzynski, P. and Van Kan, J.A.L. (2007). Botrytis cinerea: the cause of grey mould disease. Molecular Plant Pathology 8: 561-580

Wu, F.; Guan Z. and Whidden, A. (2012). Strawberry Industry Overview and Outlook, University of Florida.
Zaker, M. (2014) Antifungal evaluation of some inorganic salts against three phytopathogenic fungi. International Journal of Agriculture and Crop Sciences.14:1352-1358.

Zamani, M., Sharifi-Tehrani, A., Ahmadzadeh, M., Behboudi, K. and Hosseininaveh, V. (2008). Biological control of Penicillium digitatum on oranges using Pseudomonas spp. Either alone or in combination with hot sodium bicarbonate dipping. Australasian Plant Pathology, 37: 605-608.

\title{
فاعليه المعامله ببعض المبيدات والأملاح لمكافحه عفن الثمار الرمادى(بوتريتس سينيريا) فى
}

\section{الفراولة}

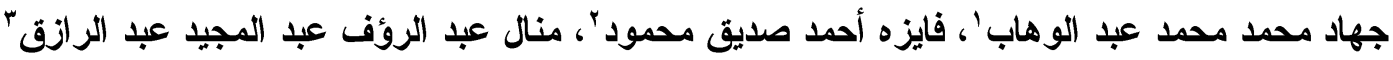 \\ 'قسم بحوث أمر اض الخضر - معهد بحوث أمر اض النباتات- مركز البحوث الزر اعيه - الجيزه - مصر

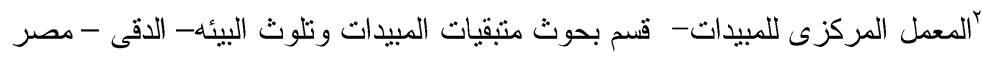

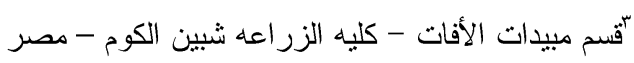

نم دراسه التأثثر التثبيطى للمبيدين(iprodione and mixture of cyprodinil+flydioxonil) و الملحين (بيكربونات وبنزوات الصوديوم) وذلك منفردين أو مخاليطه فى المعمل وكذلك فى الحقل لمكافحه عفن الثمار الرمادى فى الفراولة. وجد أن كلا من المبيدين و الملحين ومخاليطهم لهم تأثير مثبط على النمو الميسليومى للفطر بوترينس

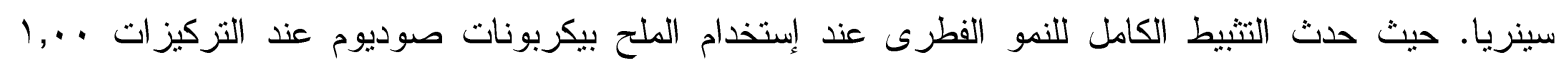

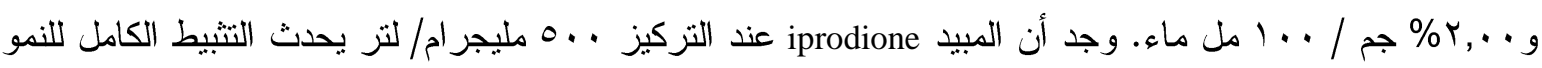

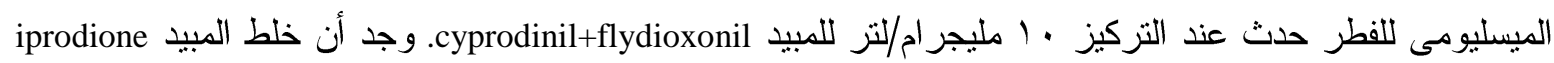

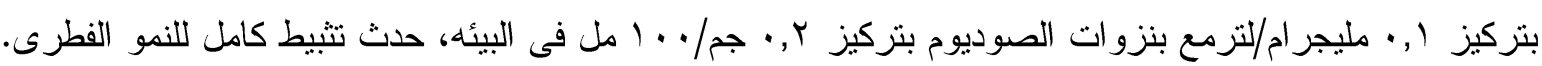

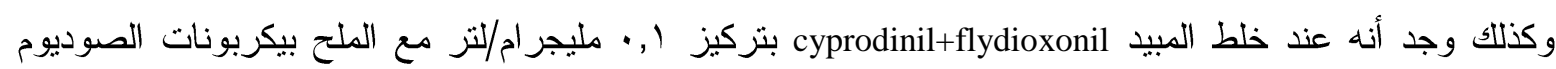
عند تركيز r, ، جم/ . (، حدث تثبيط كامل للنمو الميسليومى للفطر . وعلى العكس من ذلك وجد أن خلط المبيد

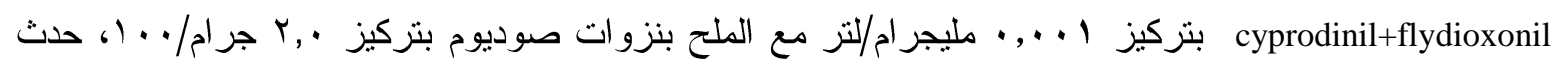
تثبيط كامل للنمو الميسليومى للفطر.

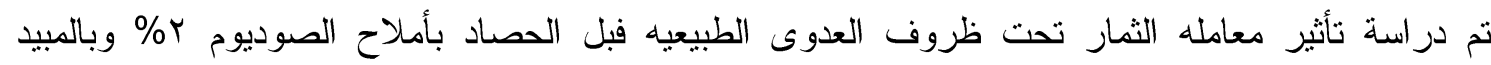
الفطرى بالتركيزات المختلفه سواء كمعامله منفرده أو مختلطه وتأثير ذلك على فلى فترات الحصاد المختلفه

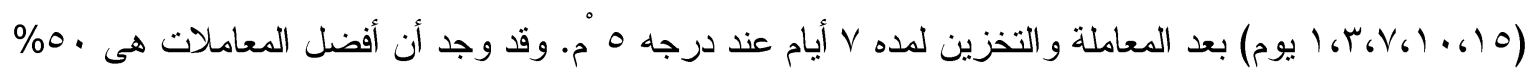
o cyprodinil+flydioxonil

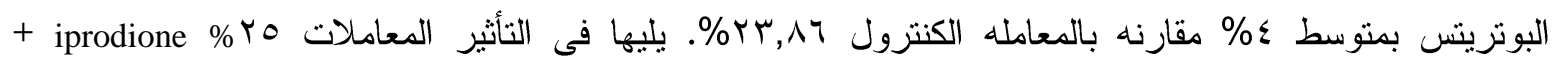




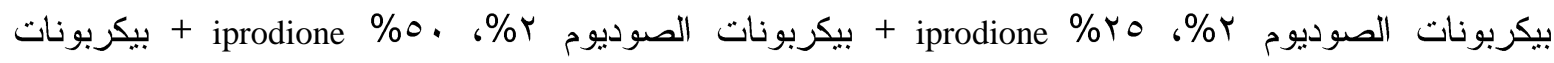

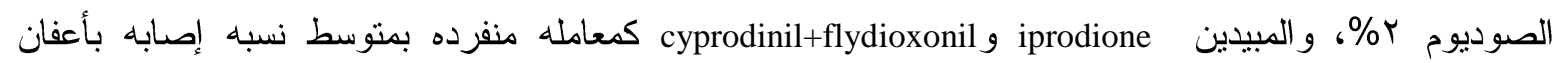

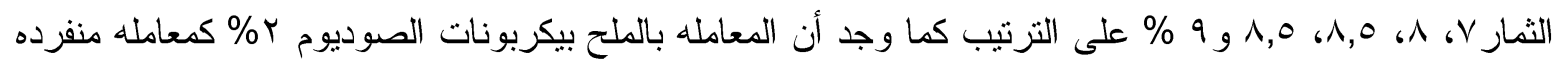

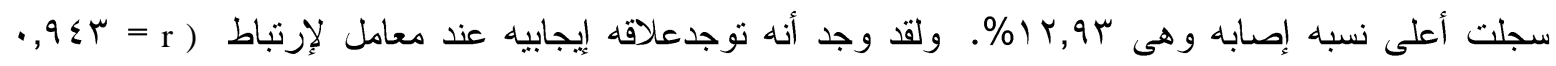

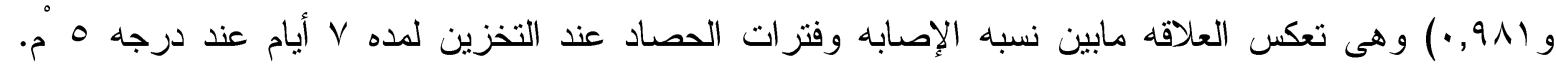
وكذلك وجد أن نشاط الانزيمين بكتينز وسليوليز مرتبط بزياده نسبه لإصابه بعفن الثمار. حيث وجد أن متبقى

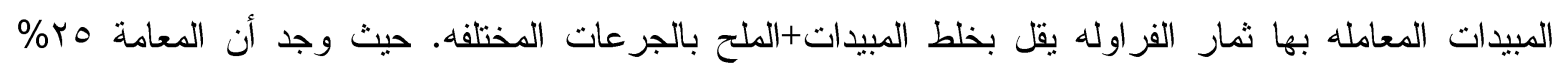

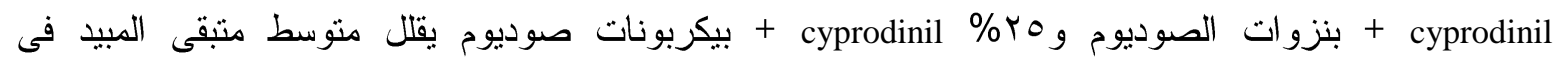

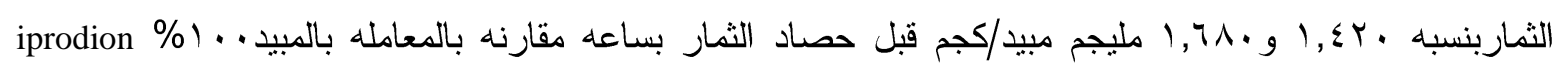

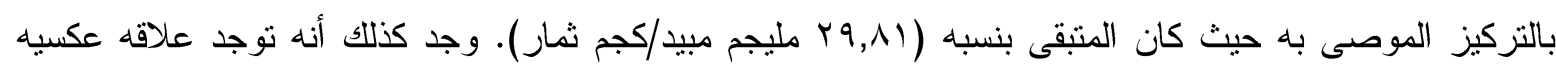

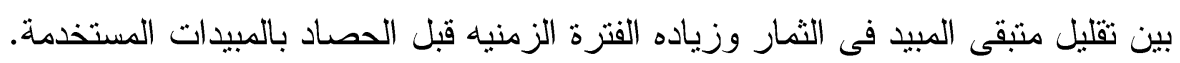

